J. Asiat. Soc. Bangladesh, Sci. 47(1): 91-97, June 2021 DOI: https://doi.org/10.3329/jasbs.v47i1.54189

- Short communication

\title{
A STUDY ON WATER QUALITY OF HAIL HAOR ECOSYSTEM OF BANGLADESH
}

\author{
M.J. UDDIN ${ }^{1} *$, ARAFAT RAHMAN ${ }^{1}$, MD. OVI-UZ-ZAMAN ${ }^{1}$, \\ SHARMIN RAHMAN ${ }^{1}$, MD. NURNABI ${ }^{2}$ AND KESHAB K. ADHIKARY ${ }^{3}$ \\ ${ }^{I}$ Department of Soil, Water and Environment, University of Dhaka, \\ Dhaka-1000, Bangladesh \\ ${ }^{2}$ Department of Applied Chemistry and Chemical Engineering, University of Dhaka, \\ Dhaka-1000, Bangladesh \\ ${ }^{3}$ Center for Environment and Energy Research (CEER), Ghent University Global \\ Campus, 119-5 Songdo-Munhwa-ro, Yeonsugu, Incheon-21985, Republic of Korea
}

During the last few decades, agricultural activities have been expanded in the wetland areas of Hail haor, which affected the wetland ecosystem adversely. There are some common natures of pollutions with domestic sewage, pesticides, insecticides, fertilizers, and industrial pollutants discharged from the upper catchment tea gardens and forest sites. The other threats are flood control dams, conversion of wetlands for agriculture or brickfields, human settlements, deforestation, extraction of sands or peats, algal blooms, etc. Therefore, water quality control is a top-priority agenda in many parts of the world (WHO 2011) and of course in Bangladesh. It becomes very important to assess the water quality of the haor basin ecosystem. For this reason, a study was conducted to analyze some important physicochemical parameters of water resources of the Hail haor ecosystem. Water samples were collected in four seasons viz monsoon (June-August), summer (September-November), winter (December-February) and post winter (MarchMay) from some selected spots. The bottles used for sampling were rinsed with deionized water and dried. At each sampling station, the sampling bottles were rinsed at least three times before samples were collected by immersing about $10 \mathrm{~cm}$ below the surface water. Water samples were collected in clean and opaque screw capped plastic bottles, wrapped up with aluminum foil, preserved in the refrigerator. The samples were filtered through $0.45 \mu \mathrm{m}$ micro-pore Whitman filter paper and were kept at freeze to avoid further contamination. The parameters pH, EC (Electrical Conductivity), TDS (Total Dissolved Solids) and DO (Dissolved Oxygen) were measured by digital pH, EC, TDS, and DO meters, respectively. A digital thermometer determined the temperature of the water. The $\mathrm{BOD}_{5}$ was determined by measuring initial $\mathrm{DO}_{1}$ and $\mathrm{DO}_{5}$ after 5 days incubation in the dark condition at $20^{\circ} \mathrm{C}$ (Klein and Gibbs 1979). Alkalinity was measured as $\mathrm{CaCO}_{3}$ by

*Corresponding author: <juswe@du.ac.bd>. 
titration of the water samples to an endpoint $\mathrm{pH}$ of 4.5 corresponding to the endpoint of the bromocresol green-methyl red indicator (APHA 2012). Ammonia-N contents of water were analyzed by micro Kjeldahl's distillation method (Jackson 1967). Nitrate-N contents were determined by the colorimetric method using a fixed absorbance in a UV-VIS spectrophotometer (Armstrong 1963). COD, chloride, and sulfate were determined by the USEPA Reactor Micro-digestion method, Titrimetrically, and Turbidimetrically, respectively (Jirka and Carter 1975, APHA 2012). The results of all the water quality parameters for Hail haor is presented in Table 1.

The highest temperature of Hail haor water was $29.78^{\circ} \mathrm{C}$ in June, and the lowest was $22.45^{\circ} \mathrm{C}$ in February, whereas the mean temperature was $25.90^{\circ} \mathrm{C}$. In the winter season, the water temperature varies from 22.45 to $24.75^{\circ} \mathrm{C}$ and 26.20 to $27.0^{\circ} \mathrm{C}$ during the dry season, which was found within the standard limits (EQS 1997 and DoE 2017). In River water temperature, the DoE standard for sustaining aquatic life is 20 to $30^{\circ} \mathrm{C}$ both in dry and wet seasons. The highest $\mathrm{pH}$ of Hail haor water was recorded at 7.67 in February, and the lowest was 6.88 in June, with the mean $\mathrm{pH}$ value of 7.12. The standard limits of pH range were 6.5 to 8.5 (ADB 1994, EQS 1997, De 2005, WHO 2011 and DoE 2017), and the study showed that all of the values were within the standard limits. The $\mathrm{pH}$ in both wet and dry seasons was favorable for fisheries and other aquatic organisms. The highest EC of the water was found $186.75 \mathrm{ds} / \mathrm{m}$ in February and the lowest was 53.81 in June, and the mean EC was $115.63 \mathrm{ds} / \mathrm{m}$ and the standard limit of EC in water is 700 ds/m (EQS 1997, DoE 2017) and the study showed that all the observed EC were within the standard limits. The acceptable range of EC for irrigation water is $750 \mathrm{ds} / \mathrm{m}$ and aquaculture water are 800 to $1000 \mathrm{ds} / \mathrm{m}$ (ADB 1994). The measured EC of all samples was lower than acceptable limits. In the monsoon season, the flow of the water increases, which may cause the dilution of the salinity of the water, while in the dry season, the flow of the surface water decreases which increases EC. In the winter season, the EC ranged from 93.43 to $186.75 \mathrm{ds} / \mathrm{m}$ and in the dry season, the EC varies from 53.81 to $128.53 \mathrm{ds} / \mathrm{m}$, which might be due to the seasonal variations. The highest DO of water was found $6.01 \mathrm{mg} / \mathrm{l}$ in June, and the lowest was $2.06 \mathrm{mg} / \mathrm{l}$ in April. The mean DO content was $4.40 \mathrm{mg} / \mathrm{l}$. The standard limit of DO is $5.0 \mathrm{mg} / \mathrm{l}$ (EQS 1997, WHO 2011, De 2005, DoE 2017), and the study showed that DO contents were satisfactory level and suitable for fisheries and aquatic resources except in the summer. DO contents varied from 5.01 to $6.25 \mathrm{mg} / \mathrm{l}$ during the monsoon and winter season and 1.79 to $5.08 \mathrm{mg} / \mathrm{l}$ during the dry and late winter season. According to environmental quality standards (EQS), the following requirements for DO are prescribed: $6.0 \mathrm{mg} / \mathrm{l}$ for drinking water, 4.0 to $6.0 \mathrm{mg} / \mathrm{l}$ for fish and livestock, and $5.0 \mathrm{mg} / \mathrm{l}$ for industrial application. In summer, DO contents were much 
lower than the desired limits, indicating that water quality is not satisfactory for aquatic organisms, which might be due to the presence of a higher level of organic waste pollutants. The highest TDS of the haor water was $125.73 \mathrm{mg} / \mathrm{l}$ in February, and the lowest was $45.85 \mathrm{mg} / \mathrm{l}$ in November, and the mean TDS contents were $73.36 \mathrm{mg} / \mathrm{l}$. Seasonal variation revealed that TDS ranged from 45.85 to $125.73 \mathrm{mg} / \mathrm{l}$ in the winter and 35.91 to $85.96 \mathrm{mg} / \mathrm{l}$ in the dry season. The USPH (United States Public Health) acceptable TDS is $500 \mathrm{mg} / \mathrm{l}$ (De 2005), $1000 \mathrm{mg} / \mathrm{l}, 1500 \mathrm{mg} / \mathrm{l}$, and $2000 \mathrm{mg} / \mathrm{l}$ for domestic water, drinking water, industrial water and for irrigation, respectively (ADB 1994). According to another report and the standard limit of TDS in water is $600 \mathrm{mg} / \mathrm{l}$ (EQS 1997 and WHO 2011). The TDS values were found within the standard limits.

The highest $\mathrm{BOD}_{5}$ content of the water samples was found at $2.19 \mathrm{mg} / \mathrm{l}$ in June, and the lowest was $1.02 \mathrm{mg} / \mathrm{l}$ in February, and the mean $\mathrm{BOD}_{5}$ was $1.50 \mathrm{mg} / \mathrm{l}$. The $\mathrm{BOD}_{5}$ status didn't show any significant variation among four distinct seasons because Hail haor water might not be contaminated to a large extent. The standard limit of $\mathrm{BOD}_{5}$ in water is $5 \mathrm{mg} / \mathrm{l}$ (DoE 2017). Generally, unpolluted waters typically have BOD $_{5}$ values of $2 \mathrm{mg} / \mathrm{l}$ or less (Agbaire and Oyibo 2009, Garg et al. 2010, Utang and Akpan 2012). The permissible limit for BOD for drinking water is $2 \mathrm{mg} / \mathrm{l}$, fish culture is $6 \mathrm{mg} / \mathrm{l}$, and irrigation purpose is $10 \mathrm{mg} / \mathrm{l}$ in Bangladesh standard (EQS 1997). $\mathrm{BOD}_{5}$ contents ranged from 1.02 to $1.5 \mathrm{mg} / \mathrm{l}$ in the winter season and 1.3 to $2.19 \mathrm{mg} / \mathrm{l}$ in the dry season revealed that the $\mathrm{BOD}_{5}$ concentrations are within the desirable limits for aquaculture. In the present study, COD ranged from 54.71 to $75.83 \mathrm{mg} / \mathrm{l}$ in the winter and 27.33 to 52.91 $\mathrm{mg} / \mathrm{l}$ in the dry season, demonstrating the highest COD as $75.83 \mathrm{mg} / \mathrm{l}$ in February and the lowest as $27.33 \mathrm{mg} / \mathrm{l}$ in June, and the mean COD was $52.70 \mathrm{mg} / \mathrm{l}$. COD in the unpolluted surface water is $20 \mathrm{mg} / \mathrm{l}$ or less (Agbaire and Oyibo 2009, Garg et al. 2010, Utang and Akpan 2012). A higher COD indicates a higher level of pollution (Varunprasath and Daniel 2010). It can be assumed that the study site receives a higher amount of nonbiodegradable chemical substances from surrounding sources. As a result, the water quality is not suitable for fish and other aquatic resources. It is found that the calculated ratio of mean BOD and COD matches well with the findings of Lee and Nikraz (2014). In the winter season, the alkalinity ranged from 25.85 to $28.67 \mathrm{mg} / \mathrm{l}$, and in the dry season, it varied from 24.83 to $31.67 \mathrm{mg} / \mathrm{l}$ due to the seasonal variations. The highest alkalinity was $31.67 \mathrm{mg} / \mathrm{l}$ in April, and the lowest was 24.83 in June, and the mean alkalinity was $27.75 \mathrm{mg} / \mathrm{l}$. The standard limit of alkalinity in water is $150 \mathrm{mg} / \mathrm{l}$ (DoE 2017). The studies showed that all the observed alkalinities were within the normal limit, and favorable for aquatic habitats. 


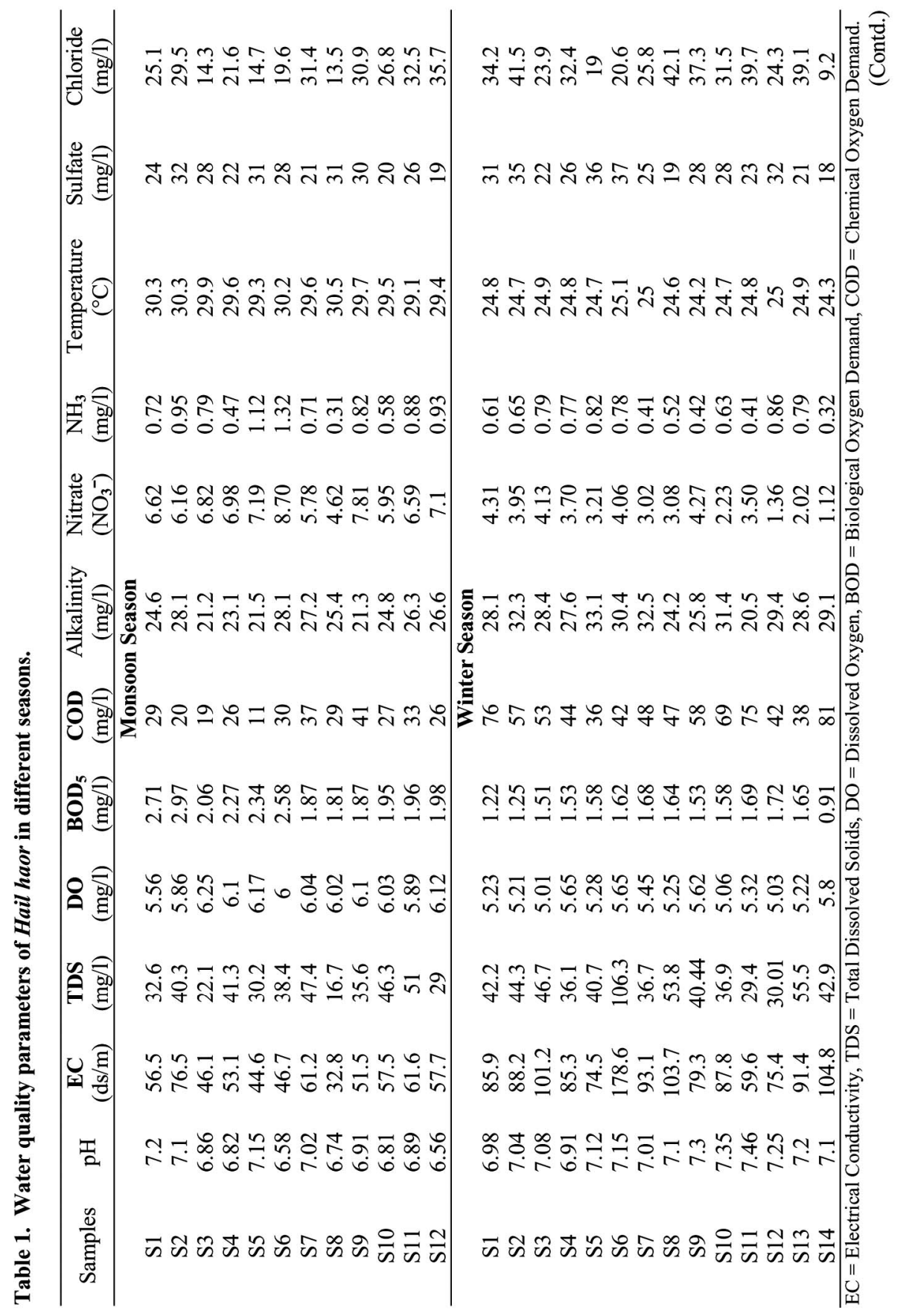




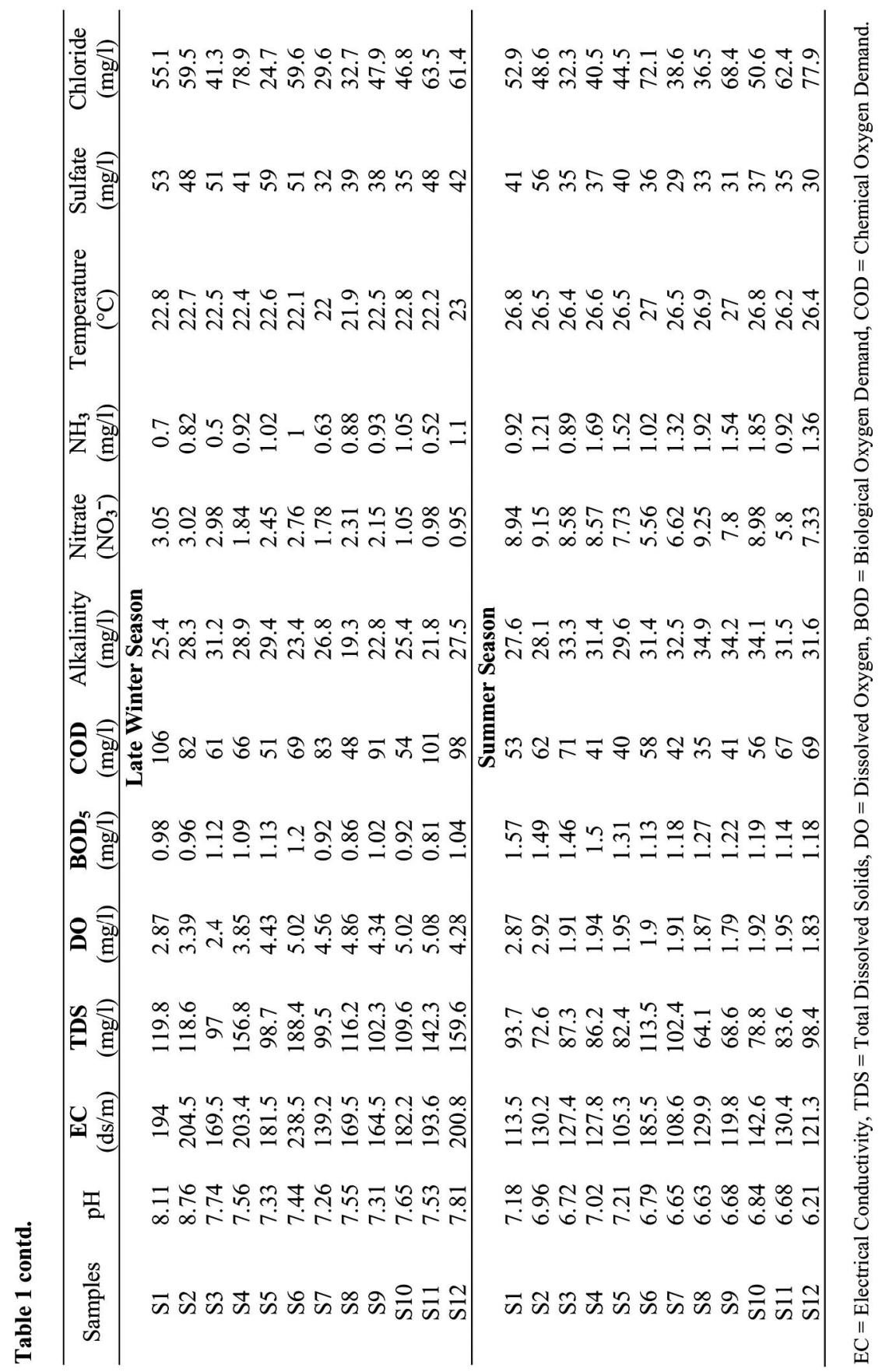


Nitrate contents were 2.21 to $3.14 \mathrm{mg} / \mathrm{l}$ during the winter and 6.69 to $7.86 \mathrm{mg} / \mathrm{l}$ during the dry season. The highest nitrate content was $7.86 \mathrm{mg} / \mathrm{l}$ in April, and the lowest was 2.21 $\mathrm{mg} / \mathrm{l}$ in February, and the mean nitrate content was $5.03 \mathrm{mg} / \mathrm{l}$. The standard limit of nitrate is $10 \mathrm{mg} / \mathrm{l}$ (WHO 2011) and according to the surface water regulation of EU 1989 (EPA 2001) the recommended limit values of nitrate were $50 \mathrm{mg} / \mathrm{l}$. The study showed that nitrate contents were at a satisfactory level for fisheries and other aquatic organisms. Ammonia content ranged from 0.63 to $0.84 \mathrm{mg} / \mathrm{l}$ in the winter season and 0.81 to 1.35 $\mathrm{mg} / \mathrm{l}$ in the dry season, reaching the highest level at $1.35 \mathrm{mg} / \mathrm{l}$ in April and the lowest at $0.63 \mathrm{mg} / \mathrm{l}$ in November, and the mean ammonia content was $0.89 \mathrm{mg} / \mathrm{l}$. According to the surface water regulation of EU 1989 report (EPA 2001), the recommended limit of ammonia ranged from 0.2 to $4.0 \mathrm{mg} / \mathrm{l}$, where, in another report suggested the limit of ammonia in water as $1.2 \mathrm{mg} / \mathrm{l}$ (ADB 1994). The study revealed that ammonia concentration in haor water was much lower compared to the recommended limits; similar observation was reported for ammonia contents for Tanguar haor water (Islam 2011). Sulfate contents were 27.21 to $44.75 \mathrm{mg} / \mathrm{l}$ during the winter season and 26 to $36.67 \mathrm{mg} / \mathrm{l}$ during the dry season, touching the highest value of $44.75 \mathrm{mg} / \mathrm{l}$ in February, the minimum value of $26 \mathrm{mg} / \mathrm{l}$ in June, and the mean sulfate content was $33.65 \mathrm{mg} / \mathrm{l}$. The standard limit of sulfate is $250 \mathrm{mg} / \mathrm{l}$ (WHO 2011), and the regulation of EU 1989 (EPA 2001) recommended the limit as $200 \mathrm{mg} / \mathrm{l}$. The study revealed that the sulfate contents were at a satisfactory level. Chloride contents were 30.04 to $50.07 \mathrm{mg} / \mathrm{l}$ during the winter and 24.26 to $52.1 \mathrm{mg} / \mathrm{l}$ during the dry season The highest chloride content was $52.1 \mathrm{mg} / \mathrm{l}$ in April and the lowest was $24.26 \mathrm{mg} / \mathrm{l}$ in June and the mean chloride content was 39.11 $\mathrm{mg} / \mathrm{l}$. The standard limit of chloride is $250 \mathrm{mg} / \mathrm{l}$ (EQS 1997, EPA 2001), and the study showed that chloride contents were satisfactory and suitable for aquaculture and other aquatic resources.

Concerning all measured parameters, it could be settled that the only COD level was much higher than the standard level in the study site. The reason behind this is that along its course Mono River receives many types of point, and non-point sources of pollutants from industries, agricultural fertilizer residues, and municipal wastes, rural market discharges, agrochemicals, and pesticides used in upstream tea gardens. So, it is suggested to control point and non-point sources of pollutants immediately to restore the water quality of the Hail haor ecosystem.

\section{References}

ADB (Asian Development Bank), 1994. Training manual for environmental monitoring. Engineering Science Inc., USA, pp. 2-16. 
Agbaire, P. O. and I. P. Oyibo. 2009. Seasonal variation of some physico-chemical properties of borehole water in Abraka, Nigeria. African J. Pure and Appl. Chem. 3(6): 116-118.

Armstrong, F. A. J. 1963. Determination of nitrate in water by ultraviolet spectrophotometry method. Analytical Chem. 35: 1292-1294.

APHA, 2012. Standard methods for the examination of Water and Wastewater. American Public Health Association, American Water Works Association, Water Environment Federation, Washington, D.C.

DoE, 2017. Surface and Ground water quality report 2016. Department of Environment. Ministry of Forest and Environment. Government of the Peoples' Republic of Bangladesh. pp. 1-80.

De, A. K. 2005. Environmental Chemistry. 5th edition. New Age International Publishers, India. pp. 242.

EPA, 2001. Parameters of water quality interpretation and standards. Environmental Protection Agency. Ireland. pp. 26-104.

EQS (Environmental Quality Standard), 1997. Bangladesh Gazette, registered no. DA-I. Ministry of Environment and Forest. Department of Environment, Government of the People's Republic of Bangladesh, Dhaka.

Garg, R. K., R. J. Rao, D. Uchchariya, G. Shukla and D. N. Saksena, 2010. Seasonal variations in water quality and major threats. African J. Environ. Sci. and Technol. 4(2): 61- 76.

Islam, K. A. 2011. Ecology and Biodiversity of the Tanguar Haor - A Unique Wetland of Bangladesh. Dhaka. pp. 1-34.

Jackson, M. L. 1967. Soil Chemical Analysis. Prentice Hall, Inc. Englewood Cliffs, New Jersey, USA. 227-267.

Klein, R. L. and C. Gibbs. 1979. Standard Methods for the Examination of Water and Wastewater. J. Water Pollu. Control Federation 51(9): 2257.

Jirka, A. M. and M. J. Carter. 1975. USEPA Reactor Digestion Method for COD analysis. Analytical Chem. 47(8): 1397-1398.

Lee, A. H. and H. Nikraz. 2014. BOD:COD ratio as an indicator for pollutants leaching from landfill. J. Clean Energy Technol. 2(3): 263-266.

Utang, P. B. and H. E. Akpan. 2012. Water quality impediments to sustainable aquaculture development along selected segments of the New Calabar River, Niger Delta, Nigeria. Research J. Environ. and Earth Sci. 4 (1): 34-40.

Varunprasath, K. and N. A. Daniel. 2010. Physico-chemical parameters of River Bhavani in three sites, Tamilnadu, India. Iranica J. Energy and Environ. 1(4): 321-325.

WHO, 2011. Guidelines for Drinking water quality. 4th edition. WHO press, Geneva, Switzerland. 